\title{
Forensic Science and Scientific Measures of Criminal Identification in British India
}

\author{
Saumitra Basu* \\ (Received 26 November 2018; revised 14 May 2019)
}

\begin{abstract}
Like every civilized society, India also had a crime and criminal justice system since ancient times. Specifically after the 1857 rebellion, the British reformed the whole penal law and introduced forensic science for scientific certainty in the criminal justice system. The present paper attempts to understand the historical roots of forensic science in India with emphasis to explore the circumstances which prompted the British to initiate forensic science in India, perception of crime developed by the colonial rulers and finally the historical consequences of the development of forensic institutions in different parts of colonial India. Finally the study reveals that introduction of forensic science for crime investigation and institutionalization of crime came as a new colonial discourse.
\end{abstract}

Key words: British, Criminal identification, Forensic, India, Legal reforms, Science.

\section{INTRODUCTION}

Since ancient times India had its own way of crime identification and criminal justice system (Shashi Rekha, 1989, p. 2). But the application of magnificent and specialized scientific discipline i.e. 'forensic science' was introduced by the British for taking scientific steps towards greater approximation of truth. The word 'forensic' has been derived from the Latin word 'forensis', meaning 'belonging to the market place or forum' where legal cases were tried and pleaded. Thus the term 'Forensic Science' means the application of the knowledge of science for the purposes of law and justice (Aggarwal, 2001, pp. 1-27). It is multi-disciplinary in nature and a lot of disciplines stemming from biology, chemistry, physics and geology to psychology are embedded in it.

The objective of the present paper is to understand the historical roots of forensic science in India over a period which approximately spans from the mid nineteenth century to mid twentieth century with a focus on the nature of - (i) socio historical circumstances that inspired the British to initiate forensic science in India? (ii) what was the perception of crime developed by the colonial rulers? and (iii) what kind of forensic institutions were developed in different parts of colonial India? The paper attempts to trace development and use of forensic science in civil and criminal investigation during British period and explores the extent to which the forensic science has proved useful in investigation and trials. In such an endeavour, several archival documents as primary sources and different monographs, reports, micro films etc. as secondary sources were used. Systematic study of the different legal, administrative, judicial and crime records of the $18^{\text {th }}$ and $19^{\text {th }}$ century India reveals that with the changing social circumstances, late eighteenth and early nineteenth century witnessed billowy wave in the field of law, justice and administration. Many legal reforms were made over the criminal justice system and new scientific tools for criminal

\footnotetext{
* Research Associate, INSA, Corresponding address: AVISHIKTA - I, Flat 3B-302, 369/1, Purbachal Kalitala Road, Kolkata 700078, Email: bsoumitra2001@gmail.com.
} 
investigations were introduced. The works which provide the background materials for the present study are - origin and evolution of police as an institution in Bengal (Chattopadhyay, 2000, p. 33); colonial police force (Majumdar,1960, p. 31); evolution of chowkidari system in the Bengal (Bhowmik,1991, pp. 60-80); police and control in South India (Arnold,1976, pp.3-16); social control and public order (Chakrabarti, 2009, pp. 171-172); dacoity in nineteenth century Bengal (Das, 2007 pp. 1-7); rural crime (Yang, 1979, pp. 289-306); deeper areas of class and antagonism (Mukhopadhyay, 2006); criminals in the prison (Sen, 2007, p. 9); criminal occurrence in Bengal (Mukherjee, 1995); changes in criminal law (Singh, 1998, p. 89); forensic science and criminal prosecution in India (Grover and Tyagi, 2014, pp. 1-7); evolution of criminal justice system in ancient India (Tripathi, 2018 pp. 153-157); forensic medicine in India (Mittal et al., 2007, pp. 89-91); Indian pioneers of fingerprint science (Sodhi and Kaur, 2005, pp. 185-191); admissibility of scientific evidence in Indian courts (Umamaheswari, 2014, pp. 1-5) and history and development of forensic science in India (Tewari and Ravikumar, 2000, pp. 303-308) etc. All the above mentioned works covered either provincial or national level perspective in their own merit. The next section tries to highlight how colonial rulers perceived crime and to prevent crime how crime identification was institutionalized?

\section{Colonial perception about Crime}

Mark Brown in his article 'Ethnology and Colonial Administration in Nineteenth century British India: The question of Native Crime and Criminality' demonstrated that the evolution of more detailed information on crime and criminals was slow, but it also mirrored in important ways the contours of ethnographic thinking as that science emerged and was shaped and reshaped from the early nineteenth century onwards
(Brown, 2003, p.209). Next to concept of forensic science, it is crucial to understand the perception of crime by the colonial rulers. How did they identify a person as criminal or what were the causes of criminality? In keeping with western legal tradition, the British chose to pass laws in order to define who was a criminal and how they should be treated. Due to social and cultural differences, no similarities thus existed between Britain and India regarding the concept of crime or criminals. However, the word 'crime' is derived from the Latin root cernō, meaning 'I decide, I give judgment'. Originally the Latin word crimen meant 'charge' or 'cry of distress'. However, the word crime owes its genesis to the the Ancient

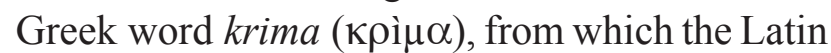
cognate derives, which is synonymous with the Sanskrit word 'krama', meaning social order. Thus the word crime is applied to those acts that go against social order and are worthy of serious condemnation (Huda, 1765, pp. 3-19).

Sir William Blackstone in his 'Commentaries on Law of England' defined crime "as an act committed or omitted in violation of Public Law forbidding or commanding it" (Blackstone, 1765, pp. $\mathrm{i}-\mathrm{iv})$. Since there is no satisfactory definition of crime, the Indian Penal Code, 1860 uses the word 'offence' in place of 'crime'. Section 40 of the IPC defines 'offence' as an act punishable by the Code. An offence takes place in two ways, either by commission of an act or by omission of an act. When a crime is done, any member of the public can institute proceedings against the person accused of the offence (IPC, 1860) ${ }^{1}$.

While describing the colonial perception about crime in the book 'Terror, Crime and Punishment: Order and Disorder in Early Colonial Bengal 1800 - 1860, Chakrabarti (2009, pp. 171-172) described that the attempt of the colonial administrators to brand some of the Indian castes, classes and tribes as criminal, does not bear

${ }^{1}$ The Indian Penal Code: Law Commission of India, Government of India, Delhi, 1860. 
scrutiny. Any number of official documents may be cited to show that in colonial India the relation between economic condition and crime was very close. The colonial perception of criminal communities was a typical European way of looking at India.

In search of historical definition of crime from different historical records, the present author tried to understand what the colonial rulers and regulations perceived as crime. The study reveals that it is difficult to define what the historical definition of crime in colonial India was. The colonial rulers who codified the criminality of Indians had all kinds of prejudices against the people whom they ruled. There was hardly any scope to accommodate the Indian perception in the colonial jurisprudence regarding crime and criminality. The legal perception of crime and criminality in colonial India was essentially a colonial construction. It can be said that, administrative discourse in colonial India sought to classify lower castes in the caste hierarchy and aboriginal tribes as criminals. Colonial administrative and metropolitan ideas and practices were thus used to classify these groups as 'criminals' (Kumar, 2004, pp. 1078-1087). To identify these crimes and criminality, the power of the regime was rhetorically constructed through the language of legality (Mukherjee, 2003, pp. 96105). As a consequence, to address the scientific truth and trust at the intersection of law, science and medicine, the colonial rulers introduced scientific investigations in British India. The basic purpose was to address the key anxiety of the colonial rulers like - fake and false, perjury, murder, dacoity, forgery, fabricated evidence, false statements which will be scientifically justified for detecting true victims. To fulfil this new venture, different forensic institutions described below were established in different parts of (specifically in colonial Bengal) colonial India since 1849 to early part of $20^{\text {th }}$ century. The development of different forensic institutions in British India has been described next.

\section{Institutionalization of Criminal IDENTIFICATION}

\subsection{Chemical Examiner's Laboratory}

Since late eighteenth to the beginning of the nineteenth century, death by poison was a common phenomenon which posed a new challenge to the law enforcement agencies of the colonial rulers. It was a hard task how to detect or isolate different categories of poison which causes deaths. To eradicate this, a chemical examiner's laboratory was established in British India to render independent scientific service to criminal justice administrative system. The first chemical examiner's laboratory in India came into existence in Madras in the year $30^{\text {th }}$ October 1849 with P Thomas Ray as first chemical examiner who was a surgeon. After realizing the importance of this venture, similar laboratories were established at Calcutta in the year 1853 and subsequently followed by Agra (1864), and Bombay (1870). All these laboratories maintained a network across British India (Tiwari and Nanda, 2001, pp. 1-25). The laboratories were equipped to analyse toxicological samples of human and animal organs, bloodstains, excreta, soil, food, stomach contents, clothing, bedding, weapons, food, drugs, various excisable materials and cooking utensils. These scientific reports helped a lot to the criminal justice system and simultaneously made a new discourse on poisoning, serology, bacteriology, drug adulteration, chemical warfare, and explosives during the British Empire. In course of time, all these laboratories provided judicial support to the neighbouring states and union territories also ${ }^{2}$.

\footnotetext{
2 Report of the Chemical Examiner to Government, Punjab, for the year 1879, Government Civil Secretariat Press, Lahore, 1880, 17-18 (IOR/V/24/418) (BL, London).
} 


\subsection{Anthropometric Bureau}

Since mid-nineteenth century onwards and even after the establishment of the chemical examiners' laboratories in different parts of India, still criminal identification posed a challenge to the British administration. Different new types of crime like dacoity, burglary, thievery and even murder became very common phenomena. In spite of the invention of photography, the Criminal Investigation Department (CID), very often faced a common problem of true criminal identification because in most cases, the criminals changed their appearance after crime. Most of the time, CID police had to deal with a number of persons who are habitual criminals of dangerous characters but treated as first offenders because they hide their correct names and antecedents. In such a panorama, the necessity of devising some means for identifying the criminals led to the introduction of 'anthropometric system' for the purpose of criminal identification. Like other countries of the world, India also adapted Alphonse Bertillon's anthropometric system in $1878^{3}$.

But according to need and situation, the Bengal Police made some modifications in the number of measurements of body parts. Instead of ten measurements, they modified six measurements (length of head, width of head, length of left middle finger, length of left forearm, length of left foot and height) along with the impression of the ball of the left thumb and a more prominent permanent marker which under the earlier French system had not been taken. Ultimately, the Secretary, Government of India in his letter no. 263, dated $10^{\text {th }}$ May 1892 officially instructed H J S Cotton, the Chief Secretary of Bengal and also in other provinces to introduce Bertillon System of Anthropometry for identification of habitual criminals and offenders ${ }^{4}$. Finally, for maintaining anthropometric records of habitual criminals and offenders, an Anthropometric Bureau was established at Writer's Building, Calcutta in the year $1892^{5}$.

\subsection{Finger Print Bureau}

Sir William Herschel was one of the first to advocate the use of fingerprinting in the identification of criminal suspects. While working for the Indian Civil Service, he began to use thumbprints on documents as a security measure to prevent the then-rampant repudiation of signatures in 1858. In 1877 at Hooghly (near Calcutta) he instituted the use of fingerprints on contracts and deeds and he registered government pensioners' fingerprints to prevent the collection of money by relatives after a pensioner's death. Herschel also fingerprinted prisoners upon sentencing to prevent various frauds that were attempted in order to avoid serving a prison sentence (Grover and Tyagi, 2014, p.1).

Even after the official application of anthropometric system of criminal identification, still some incidence happened where anthropometric system could not prove criminal identification. Two cases of professional robbery by poisoning were reported within a couple of days in the Darbhanga district of Bihar. The detective police entrusted with the enquiry, came to the conclusion that the culprit was one. This type of incidence was not a single one; many other similar cases were reported in different parts of India. In such a context to prevent this occurrence, the British Government (specifically Edward Richard Henry, the Inspector General of Police) felt the necessity to invent some identifying marks which is inimitable ${ }^{6}$.

\footnotetext{
3 Bengal Police: Criminal Identification by Means of Anthropometry, IOR/L/PJ/6/416, File 436: 1895, British Library, London.

4 Proceedings- September, Nos. 87-90, Home Department, Police Branch, Simla Records, National Archives of India, New Delhi

5 Report on Anthropometric measurement System for the Identification of Old Offenders, Judicial Department, Police File. P3-R/ 18,1-3 No. 48-51, 1896, West Bengal State Archives.

6 Letter to the Chief Secretary, Government of Bengal from E.R Henry, Inspector General of Police, Judicial Department, File P 3- R/18 1, 1896, West Bengal State Archives.
} 


\begin{abstract}
.. Sir Edward Henry was appointed as an assistant magistrate collector in the Indian Civil Service in 1873 and became Inspector General of Police at Bengal in 1891. He went to Galton in 1893 and learned on finger printing. When he returned to India he felt the necessity to use this unique identification as an additional aid to criminal identification. He proposed to incorporate thumb impression in the record slips including anthropometric data to eliminate vague identification of criminals (Polson, 1951, p.690).
\end{abstract}

For this purpose a committee was formed and finally passed a resolution of the Governor General in Council dated June $12^{\text {th }} 1897$, where it was directed that finger printing will be introduced throughout the British India as the official mode of criminal identification. This was a remarkable milestone of the application of science for identifying the truth. In 1897, the world's first finger print bureau was established in the Writers' Building, Calcutta, known as Bengal Fingerprint Bureau (Chatterjee, 1953, pp. 9-19). The main aim of this bureau was to standardize the methods of recording, detecting, classifying, developing and preserving finger prints. For this purpose two police sub inspectors namely Khan Bahadur Azizul Haque and Rai Bahadur Hem Chandra Bose were appointed who worked in the advancement of the science of fingerprints. Though they were named after their supervisor, Sir Edward Richard Henry but in reality 'Henry's System of Fingerprint Classification' was actually worked out by them. Azizul Haque developed a mathematical formula which helped Edward Henry to sort 10 digit fingerprint forms into a 'pigeon hole' cabinet system based on fingerprint patterns (File IOR/L/PJ/6/1752). The other person Hem Chandra Bose developed an extended system of sub classification of fingerprints, a telegraphic code for fingerprint impression (published in the form of a book 'Hints on Finger-Prints with a Telegraphic Codefor Finger Impressions in 1916' and also a system of single digit classification ${ }^{7}$. Finally, in the year 1899, the British Government declared a special act which replaced Bertillon's system of anthropometry and established the proficiency of the fingerprints for identifying the true criminals.

\subsection{Explosive Department}

In spite of changing the Indian Penal Code and also the entire legal system, the British administration could not rule peacefully. There was a significant gap between the criminal law and types of criminal activities in the society what Elizabeth Kolsky (2010, p. 35) in her book Colonial Justice in British India: White Violence and the Rule of Law described "a place of lawlessness at the centre of law's empire". Several new types of crimes were reported among which use of explosives like the introduction of nitrocompounds which causes several blasting and explosions in different parts of the country. Mention here will be made of those explosions which rocked and ravaged many parts of the country. These were the explosions of two magazines at Nari Gorge and Kach on the SindPeshin Railway in 1888, explosion of a magazine at Shelabagh on the Sind-Peshin Railway in 1890, explosion of a magazine at Antop Hill, Bombay in 1891 and explosion of a magazine at Syriam, Rangoon, in $1896^{8}$.

The Indian Explosive Act was promulgamated and came into force on $26^{\text {th }}$ February 1884 with a view to provide a comprehensive regulations regarding manufacturing, keeping, sale, conveyance and importation of explosives throughout British India ${ }^{9}$. In spite of having this

\footnotetext{
7 Bose, Rai Bahadur, Hem Chandra, File 1891-1898, Police Fingerprint Expert in India History, Calcutta Fingerprint Bureau, Mss Eur F161/ 230:1896, India Office Library, London.

8 Explosive Act, vide Government of India, Home Department, Notification No. 1747 (Public) dated 11th August 1899, Appendix - I, Petroleum and Explosive safety Organization Archive, Pune.

9 The Indian Explosive Act, 1884, IOR/L/PJ/6/121, File 621: 11th March 1884, India Office Record, British Library, London.
} 
act, when several explosions happened, for critical inspection several committees were formed. The British Government decided to appoint the Superintendent of Gun Powder Factory at Ishapur and Kirkee as Chief Inspector of Explosives for their respective areas on recommendation of Sir Vivian Majendie, Her Majesty's Chief Inspector of Explosives, United Kingdom. When the aforementioned arrangement was found not satisfactory, the Government finally decided to appoint the first Chief Inspector of Explosives as an independent authority and Major C A Myspratt Williams took over the charge as the Chief Inspector of Explosives on $9^{\text {th }}$ September 1898 , with his headquarters at Nagpur (First Annual Report, Department of Explosives, 1900). Initially the Chief Inspector of Explosives was being assisted by the Superintendent and the Assistant Superintendent of the Ordinance Factories at Ishapur and Kirkee. Later for better functioning, another five offices at Calcutta, Bombay, Agra, Madras and Gwalior and three sub offices at Shivkashi, Gomia and Asansol were established (Nanda and Tiwari, 2001, pp. 1-25). All these offices tried to make a network and developed competence to provide scientific clues in respect of explosives as well as the possible causes of explosions. Their expertise helped in crime investigations related to explosions and for evolving various provisions under the Explosives \& Petrolium Act.

\subsection{Handwriting Department}

From the late nineteenth to the beginning of the twentieth century several nationalistic movements created hindrance for the smooth running of the British administration. To resist all these freedom movements the British administration took strong measures. But the most difficult task was to decipher all the nationalistic secret documents related to independence movements. In such a situation, the British administration felt the necessity to establish a handwriting department which will help their administration through their secret activities. For this purpose, the post of Government Handwriting Expert of Bengal was created in the year 1904 and. C R Hardless, Superintendent in Account General's Office was appointed to this position ${ }^{10}$. Two years later, this office was shifted to Shimla under Director, Criminal Intelligence Department ${ }^{11}$. During his tenure, the work of Hardless can be divided into three categories namely - (a) evidence as to handwriting given in the courts; (b) opinions furnished to police officers in connection with the investigation of criminal offences; and (c) opinions furnished to other officers of Government in connection with the departmental enquiries ${ }^{12}$. In course of time, $C$ $\mathrm{R}$ Hardless was replaced by a police officer from Bengal Criminal Intelligence Department, F Brewester. His responsibility was to examine the Government's questioned documents ${ }^{13}$. In such a moment when swadeshi fragrances were blooming in the air, this department reached at its highest peak. As a consequence, the application of this branch of science was applied in many other cases including criminal and civil court cases. After F Brewester, R Stott from Military Accounts Department took over the charge in the year 1925 (though he was appointed in the year 1920). During World War II, this department of science took over the responsibility of secret censorship including the revealing of invisible writing and

\footnotetext{
${ }^{10}$ Government Examiner of Questioned Documents, IOR/L/PJ/6/1994, File: 218, India Office Records, British Library, London.

${ }^{11}$ Retaining the Service of Mr. C R Hardless, IOR/L/PJ/6/760, File 1330, 19th April 1906, India Office Records, British Library, London

${ }^{12}$ Retaining the Service of Mr. C R Hardless, IOR/L/PJ/6/760, File 1330, 19th April 1906, Enclosures of Despatch No. 121 of 1906, India Office Records, British Library, London.

${ }^{13}$ Maintenance Order of Mr. F Brewester, File No. F.142/30 - Judicial, Government of India, Home Department, Simla, 5th June 1930, India Office Records, British Library, London.
} 
training of military personnel. In the year 1944, V O J Hodgson was appointed for this job and continued up to the end of the British period. However, during World War II, the activities of this department gained its momentum for investigating bribery and corruption in transaction with war and supply department of India. For this purpose Special Police Establishment Act was enacted in the year 1941 which came into force in 1946. In such a way this department laid its foundation for scientific enquiry in crime investigation.

\subsection{Serology Department}

In 1901 the Austrian American immunologist and pathologist Karl Landsteiner discovered human blood groups. Even after that in British India, the crime investigators were unable to identify any red spot in the crime scene whether it is human blood or other animals' blood or something else. To fulfil this venture and realizing the importance of forensic serology, Serology Department was established in the 3 Kyd Street of Calcutta in the year 1912 which was renamed as Imperial Serologists Department on $1^{\text {st }}$ March 1916. Dr. E H Hankin was appointed as an Imperial Serologist. Later on it was renamed as Department of Serologist \& Chemical Examiner to the Government of India ${ }^{14}$. Since its inception, this institute worked in the field of forensic serology. Initially, blood group was not identified. Rather, the red spot in the crime scene was identified whether it was human blood or not. The most important thing was the examination done through chemical examination not through any immunological process. Medico-legal exhibits were received from different forensic science laboratories of the country. After serological analysis of the exhibits reports were prepared and sent to the concerned authorities. In addition to this, analysis of cases of paternity dispute and illegitimacy were also carried out in this institute.

For criminal investigation, medico legal cases from different state forensic laboratories like Raipur, Jalpaiguri, Bihar and Assam were received and thus analyzed in this institute. Analysis of origin of these exhibits were determined from stained materials like clothes, weapons, tissues, hair, saliva, semen, soil and different body fluids. However, along with these activities, VD (venereal disease) serology was one of the oldest and important sections of this institute. Since its inception, diagnosis sections of veneral diseases were created not only for the mere diagnosis but also for internal quality control of the VDRL Antigen and standardization of VDRL Antigen produced in Antigen production section. Still now this section is recognized as an authentic antigen for non specific serological test for diagnosis of STI (sexually transmitted infections) ${ }^{15}$.

\subsection{Foot Print Section}

Since the end of the nineteenth century, the British administration felt the necessity to identify foot print available in the crime scene. Though it was true that in certain parts of India, professional trackers used to track down criminals but those trackers were entirely illiterate and unable to apply scientific way of investigation properly. In Rajputana they were known as 'Khojis' and in Gujarat as 'Pogis'. In British India, there were several instances where instead of fingerprints; footprints were available in the crime scene. For scientific investigation of footprints, G W Gayer, Inspector General of Police, published a manual 'Footprint: As an Aid to the Detection of Crime for the Police and Magistracy' in the year 1909 with lithographic plates of footprints. Ultimately in the year 1915, a Footprint section was formed under the CID Department of Bengal. The basic

\footnotetext{
${ }^{14}$ Proceedings of the Department of Imperial Serology, Assistant Surgeon employed in the Serology Department, Financial Department, Medical, K.W. File No. 3-C/13,22-25 May 1913, West Bengal State Archives, West Bengal.

${ }^{15}$ First Annual Report of the Institute of Serology, Govt. of India, 2011.
} 
objective of this section was to provide scientific clue analysed from footprint for criminal investigation.

\subsection{Note Forgery}

Since the late nineteenth century, the subject which has been forced to the attention of the British Government was the cases of forged currency. Forged currencies have been gradually more frequent and several cases were reported where forged currency notes were reproduced apparently with fraudulent intent by means of photography. But under Indian Law, currency notes were not protected from such forgery. This matter was discussed at the Government level that the Law cannot allow to remain in its present unsatisfactory state and it should be revised on the lines of the English Forgery Law. In such a consequence, the Secretary Government of India Legislative Department in his letter dated $26^{\text {th }}$ September, 1898 proposed to amend the Law relating to the Forgery of Currency Notes and Bank Notes. Finally the Law was enacted and known as the Currency Notes Forgery Act, $1898^{16}$. Even after that the beginning of the $20^{\text {th }}$ century witnessed such a historical disaster which not only changed the rank and file of the Indian society but also the world to a great extent. World War I was one of the great watersheds of $20^{\text {th }}$ century geopolitical history which shattered the global economy to its lowest ebb. It led to the fall of four great imperial dynasties namely Germany, Russia, Austria-Hungary, and Turkey. In India, the War created a new economic and political situation which led to a huge increase in defence expenditure, financed by war loans and increasing taxes, customs duties and high income tax. Through the war years, prices increased - doubling between 1913 and 1918 - leading to extreme economic hardships for the people. As a consequence of this great economic depression, common people were unable to mitigate their daily necessities in a peaceful manner. Both poverty and hunger compelled them to choose the path of corruption and anti social means of livelihood. Even after the enactment of Currency Notes Forgery Act of 1898, as an easy means of earning, note forgery became a common source of livelihood of the masses.

In such a socio-economic and socio-political perspective, to investigate the crime of note forgery and subsequent identification of the criminals involved in these activities became a major task of the British Rāj. To resist such a crime which devalued the price of money, the British Government took a strong step and finally in the year 1917, established the 'Note Forgery Section' under the Criminal Investigation Department, Government of Bengal. The basic objective of this department was to identify the forged currency notes and to create a common awareness among the common people how to identify the fake currencies. Moreover, government mints and security printing departments at Nasik tried to detect the cases of forged currency notes in their own laboratories which helped the British administration in criminal identification of forged currency notes immensely.

\subsection{Ballistic Department}

The earliest use and spread of firearms, i.e. cannon, in the ancient Indian sub-continent can probably be traced to the second half of the fifteenth century. Babur, the founder of Mughal Empire in India, had also much to contribute to the spread of firearms in India. However, gunpowder technology is believed to have arrived in India by the mid $14^{\text {th }}$ century, but could have been introduced much earlier by the Mongols, who had conquered both China and some borderlands of India, perhaps as early as the mid $13^{\text {th }}$ century. Before 1857 there was no gun control law in India.

\footnotetext{
${ }^{16}$ Proceedings September Nos. 54 - 57, Home Department, 1898, Finance and Commerce Department, National Archives of India, New Delhi.
} 
Any Indian could own any weapon of any caliber. After the 1857 Revolt, Lord Lytton became the Viceroy of India in 1858. The Indian Arms Act of 1878 was enacted during Lord Lytton's time. By this act, no Indians could manufacture, sell, possess, and carry firearms. This law made it mandatory for any Indian wishing to own a gun to obtain a license for it. An unlicensed gun was punishable with a fine and imprisonment up to three years. Thus in one blow the British restricted the ownership of guns. In 1877 the Indian Arms Act was promulgated and it remained in force till 1947.

Since the beginning of the twentieth century, several national movements started whose main aim was to free the country from the shackles of the British Rāj. These national movements became more intensified after the First World War and specifically before the emergence of Second World War. During this war period, the application of fire arms increased. Most of the unlicensed fire arms were either locally made or easily available in the local market. Even the cartridges used in these fire arms were mostly unlicensed. This overall socio-political turmoil compelled the British administration to establish a ballistic department for controlling the misuse of fire arms. As a result, in the year 1930, a Ballistic Laboratory was established under the Calcutta Police Department and a fire arm expert was appointed whose activities helped the administration in the criminal investigation.

4. Criminal Justice Reforms and the

Colonial discourse in the Late $18^{\mathrm{TH}}$ to Mid19 $^{\text {тн }}$ Century British India

Upamanyu Pablo Mukherjee ( 2003, p. 96) in Crime and Empire - The Colony in Nineteenth Century Fictions of Crime demonstrates that in 1826, the British Parliament passed a Bill to regulate the appointment of juries in India and bring the management of the affairs of the company in line with that of Europe. Two years later, another Bill was passed for improving the administration of Indian Criminal Justice.....

After taking over the political and administrative power of the Indian subcontinent, East India Company enacted a series of administrative and legal interventions. The most important of it was the management of the criminal justice system. In such a historical context, the author explores the circumstances that prompted the British government to frame new rules and subsequent penal reforms in British India.

In the latter half of the $18^{\text {th }}$ century, the East India Company imposed an effective administrative and legal structure to establish the company Rāj in India in a radical manner (Metcalf, 1995, p. 6). The legal system neither followed European legal structure nor the Indian legal system comprehensively. The existing Criminal Justice System (CJS) primarily followed the rules of Islamic Criminal Law. The first initiative was taken by Warren Hastings in 1772 to change the judicial administration but not the substantive criminal law (Mishra, 1962, p. 280). It is important to mention that there was a delay in implementing the expected reform in the criminal law because of the notion of the 'cloudy title' (cloudy title refers to any form of claim which has been outstanding or any other obstacle like unclear deed of the property, or legal issues not yet been solved which does not allow any person to control over anything till it clear of such encumbrance) of the company (Tiwari, 2014, pp. 59-62). The 'cloudy title' of the company to the Nizamat made it slow to alter the criminal law (Rankin, 1946, p. 169). The proposition of the 'cloudy title' refers to the formal legal basis of the company's legislative power in matters relating to the criminal justice system.

The administration of criminal justice was based on Islamic law and so far as penal law is concerned it was based on criminal law. Constitutionally, the British were unable to change 
it overnight. Intentionally, the British administration tried to control the whole legal system in such a manner that Muslim judicial officials were subordinated to British judges. The British administration thought that the major loopholes of the Islamic Criminal Law were to restrict the power of the courts to enforce capital sentences. Unlike British Law, in Islamic Criminal Law, there were relatively few capital offences. Moreover, there were so many defences available that convictions for such capital offences were difficult to obtain (Peters, 2005, p. 109). According to the British, in Islamic Law, there were a number of inconsistent features, principles and rules which cannot be accepted by the government. As a result, the British felt it necessary to interfere with the Islamic criminal Law.

Gradually the British restructured the Islamic Criminal Law to British notions of justice, law and order. In the domain of criminal law, the British government introduced deterrent punishments for some virulent crimes such as gang robbery, dacoity and other similar socially disorganized activities which afflicted the social norms to a great extent ${ }^{17}$. The process of replacing and amending the Islamic Criminal law with some new approach, the British Government enacted Regulations from the time of Lord Cornwallis in 1790. The process continued till 1860, when the Penal Code (PC) finally superseded the Islamic Criminal Law. Lord Cornwallis initiated the Regulation of the Government of Bengal to modify Islamic Law of Crimes. Certain changes were introduced in the criminal law during 1790-93. Some regulations were enacted on $13^{\text {th }}$ April 1792 , specifically on unidentified murder cases. Subsequent modifications such as - Regulation IX of 1793 altered the law of evidence, Regulation XIV of 1797 substituted imprisonment for blood money (as in the case of unintentional murder).
Regulation granted relief to the persons who were in prison on account of their inability to pay blood money (Cohn, 2002, p. 67).

Other severe instances were the incidence of robbery, dacoity and burglary. All these were unbridled in the early nineteenth century British India. Suitable legislations to control all these social unrest were passed in late 1803. Regulation of 1803 abolished the conditions of robbery, Regulation IX of 1808 were implemented to check dacoity. In order to check crimes of burglary, the Regulation I of 1811 provided necessary amendment. By Regulation XVII of 1817, the law relating to adultery was rationalised and modified. In 1826, the British Parliament passed a Bill to regulate the appointment of juries in India and its management in the European line ${ }^{18}$. Further in 1828, another Bill was passed for improving the administration of Indian Criminal Justice ${ }^{19}$. Even in such a changing panorama, the Islamic Criminal Law continued till 1832 but after that it was totally abolished (Malik, 1999, p. 26).

However, through this judicial reform the company gained confidence which in turn helped them to extend their territorial domination in the subcontinent. The company began to start sustained campaigns against criminal communities like Thugee. In 1821, new policing began in earnest in India with the inception of the antithugee campaign. Throughout the next decades, a number of legislations passed to implement new policing techniques in India. The Thugee and dacoity Suppression Acts XXX 1836 was made in British India (Taylor, 1843 p.293). A series of legal acts were enacted to punish the criminals like 'Thugee' and Dacoits. Philip Meadows Taylor in his article 'On the Thugs' in the New Monthly Magazine, wrote that the thugs as a perfectly distinct class of persons who subsist almost

\footnotetext{
${ }^{17}$ M P Jain, Supra note, 12, at pp. 372.

${ }^{18}$ A Bill to regulate the appointment of juries in East India, Parliamentary papers, I, 1826, p. 93.

${ }^{19}$ A Bill for Improving the Administration of Criminal Justice in India, Parliamentary Papers, 1828, p. 46.
} 
entirely upon the produce of murders that they are in the habit of committing" (Taylor, 1833, p. 227).

The abolition of 'Thugee' was a great success by the Company's government. In such an endeavour the Company felt it mandatory to change the Indian Penal Code to establish their supremacy. Four law Commissioners of whom Lord Macaulay was the chief, prepared the draft Penal Code and submitted to the GovernorGeneral in Counsel on $14^{\text {th }}$ October 1837 . On $26^{\text {th }}$ April 1845, it was sent to a Commission for modification and necessary revision. This Commission submitted two reports, dated $5^{\text {th }}$ November 1846 and $24^{\text {th }}$ June 1847 . Here it is to be noted that since 1840 s crime increased not for the reason of brutality of the Islamic Criminal Law but for the annoyance of the Indian people against the British supremacy which caused a series of anti British activities all over the subcontinent. In the mid nineteenth century, the most important was the Indian Rebellion of 1857, a major uprising against the British East India Company (Pati, 2010, pp.1-16). After this cataclysmic effect of the 1857 rebellion, the British took over the crown and reformed the Indian Penal Code (IPC) specifically for administration and judicial sector including criminal justice system permanently. The penal reform took twelve years or more for revision and was passed into law on $6^{\text {th }}$ October 1860. The revised IPC was enacted in the year 1861 but it was different from the Bill prepared by the law Commissioner. This historical moment witnessed the amendment of three criminal laws which were Indian Penal Code, Criminal Procedure Code and the New Police Regulation. The first two laws gave the colonial administration a new shape. The last one was very significant considering the earlier experience of colonial rulers who had witnessed the utter failure of police force in controlling dreadful crimes and establishing an effective order as desired by the Company Rāj (Chan, Wright and Yeo, 2011, p. 19). After taking over the crown permanently and to control the colonial subjects more systematically and vigorously, along with legal reforms and regulations, the imperial rulers introduced forensic science as a new scientific tool of supremacy in this subcontinent.

\section{Conclusions}

In India, since ancient times well organized criminal justice system existed though the pattern of justice was quite different in different periods. But after the 1857 rebellion, the British reformed the whole penal law and new Indian Penal Code was enacted since 1861 . To establish the new criminal justice system more convincingly, British rulers introduced forensic science as a new scientific weapon of criminal justice. It was the intention of the British rulers that this new field of science will not only produce an obvious, consistent and authoritative message in the courtroom but also grounded the colonial superiority in a comprehensive manner. In such an endeavour, institutionalization of crime investigation came as a new colonial discourse and establishment of different forensic institutions in different Presidencies. In such a context, enactments of different legal acts were of great importance which not only created a new vista in the measure of true criminal identification for scientific certainty but also drastically altered the concept of crime to a great extent. It is worth mentioning that from mid nineteenth to mid twentieth century, this span of hundred years witnessed the making of a profession to which the label 'forensic science' could reasonably be attached. After independence this magnificent science has developed and progressed as one of the largest tool for crime detection and solving varied medico-legal problems. In the present era, this sector is one of the most vibrant and fastest growing segments of global science which caters to the justice of the teeming millions so far as the challenge of global crime is concerned. 


\section{BIBLIOGRAPHY}

Aggrawal, Anil. Introduction to Forensic Medicine and Legal Procedures Prevalent in India - Part I, Journal of Forensic Medicine and Toxicology, 2.1 (2001):127.

Arnold, David. The Police and Control in South India, Social Scientist, 4.12 (1976):3-16.

Bhowmik, Saraj Kumar. Rural Police and Local Justice in Bengal, 1772 - 1870, Nalanda Publications, Calcutta, 1991.

Blackstone, Sir William. Commentaries on the Laws of England (1765-1769), Vol.I, Clarendon Press, Oxford, 1765.

Brown, Mark. Ethnology and Colonial Administration in Nineteenth century British India: The question of Native Crime and Criminality, The British Journal for the History of Science, 36.2 (2003):201-219.

Chakrabarti, Ranjan. Terror, Crime and Punishment: Order and Disorder in Early Colonial Bengal 1800 - 1860, Readers Service, Kolkata, 2009.

Chan, Wing Cheong; Wright, Barry and Stanley Yeo. Codification, Macaulay and the Indian penal Code: The legacies and Modern Challenges of Criminal Law Reform, Routledge, London, 2011.

Chatterjee, Salil Kumar. Finger, Palm and Sole Prints, KOSA Publishers, Calcutta, 1953.

Chattopadhyay, Basudeb. Crime and Control in Early Colonial Bengal: 1770-1860, K P Bagchi, Kolkata, 2000.

Chroust, Anton-Hermann. Legal Profession in Ancient Republican Rome, Notre Dame Law Review, 30.1.5(1954):97-148.

Code of Criminal Procedure Amendment Act, 1991.

Cohn, Bernard S. Law and the colonial State in India, in Bernard S Cohn, Colonialism and its Forms of Knowledge: The British in India, Oxford University Press, New Delhi, 2002.

Das, Suranjan. Behind the Blackened Faces: The 19th Century Bengali Dacoits, Economic and Political Weekly, XLII, 35 (2007):1-7.

Grover, Nivedita and Isha Tyagi. Development of Forensic Science and Criminal Prosecution-India, International Journal of Scientific and Research Publications, 4.12 (2014):1-7.
Huda, S S. The Principles of The Law of Crimes in British India, Clarendon Press, Oxford, 1765.

Kolsky, Elizabeth. Colonial Justice in British India: White Violence and the Rule of Law, Cambridge University Press, Cambridge, 2010.

Kumar, Mukul. Relationship of caste and crime in colonial India, Economic \& Political Weekly, 39.10 (2004):1078-1087.

Madhurima, Sen. Prisons in Colonial Bengal 1838-1919, Thema, Kolkata, 2007.

Majumdar, Nemai. Justice and Police in Bengal 1765 1793: A Study of the Nizamat in Decline, Farma KLM, Calcutta, 1960.

Malik, Shahdeen. Historical Discourse on Colonial Criminal Law, Journal of the Asiatic Society of Bangladesh, 44.1 (1999):26.

Mishra, B B. Judicial Administration of the India Company in Bengal: 1765-1783, Motilal Banarasidass, Delhi, 1962.

Mittal, Shilekh; Mittal, Sonia and Mittal, Moneeshindra Singh. Evolution of Forensic Medicine in India, Journal of Indian Academy of Forensic Medicine, 29.4 (2007):89-91.

Mukhapadhyay, Anindita. Behind the Mask the Cultural Definition of Legal Subject in Bengal 1715-1911, Oxford University Press, New Delhi, 2006.

Mukherjee, Arun. Crime and Public Disorder in Bengal: 1861- 1912, Kolkata, K P Bagchi, 1995.

Mukherjee, Upamanyu Pablo. Crime and Empire: The Colony in Nineteenth Century Fictions of Crime, Oxford University Press, Oxford, 2003.

Nanda, B B and Tiwari, R K. Forensic Science in India: A Vision for the Twenty First Century, Select Publication, New Delhi, 2001.

Palit, Chittabrata, Tensions in Bengal Rural Society: Landlords, Planters and Colonial Rule, 1830-1860, Progressive, Calcutta, 1975.

Pati, Biswamoy. The Great Rebellion of 1857 in India: Exploring Transgressions, Contests and Diversities, Routledge, London, 2010.

Peters, Rudolph. Crime and Punishment of Islamic Law: Theory and Practice from the Sixteenth to the Twenty First Century, Cambridge University Press, Cambridge, 2005. 
Polson, Cyril John. Finger Prints and Finger Printing: An Historical Study", Journal of Criminal Law and Criminology, 41.4(1951):495-517.

Rankin, G C. Background to Indian Law, Cambridge University Press, Cambridge, 1946.

Shashi, Rekha, P. The ancient Indian administration with special reference to Arthasastra, Manu and Yajnavalkya, Cosmo Publications, New Delhi, 1996.

Singh, Radhika, A Despotism of Law: Crime and Justice in Early Colonial India, Oxford University Press, New Delhi, 1998.

Sodhi, G S and Kaur, Jasjeet. The forgotten Indian pioneers of fingerprint science, Current Science, 88.1(2005):185-191.

Taylor, Philip Meadows. On the Thugs, New Monthly Magazine, 38 (1833):227.

Taylor, Philip Meadows. State of Thuggee in India, British and Foreign Review, xv.29 (1843):293
Tewari, R K and Ravikumar, K V. History and Development of Forensic Science in India, Journal of Postgraduate Medicine, 46.4 (2000):303-308.

Thomas, R. Metcalf, Ideologies of the Raj, Cambridge University Press, Cambridge, 1995.

Tiwari, Piyush Kumar. The East India Company and Criminal Justice: The Role of Orientalists, International Journal of Humanities and Social Science Invention, 3.4 (2014):59-62.

Tripathi, Rahul. Evolution of Criminal Justice System in Ancient India, International Journal of Multidisciplinary Research and Development, 5.1(2018):153-157.

Umamaheswari, D. Medico-Legal Aspects in the Admissibility of Scientific Evidence, International Journal of Innovative Science, Engineering \& Technology, 1, I 8 (2014):1-5.

Yang, Anand. Agrarian Origins of Crime: A Study of Riots in Saran District, India, 1886-1920, Journal of Social History, 13.2 (1979):289-306. 